\title{
Climate Change and Pesticide Loss in Watershed Systems: A Simulation Modeling Study
}

\author{
B. Chen ${ }^{*}$ \\ Faculty of Engineering and Applied Science, Memorial University, St. John's, Newfoundland A1B 3X5, Canada
}

\begin{abstract}
This paper aims at examining the impacts of climate change on pesticide loss to surface water through a modeling study. An integrated modeling system which combined a distributed pesticide loss model with geographic information system (GIS), database, and climate change scenarios was proposed. It can predict pesticide loss through runoff under climatic change conditions. A case study was used to calibrate and verify the proposed system. The atrazine loss in 2050 and 2100 was predicted under different climate change scenarios. With the global warming, the annual streamflow would augment by 3 to $5 \%$ and the total atrazine losses would also gradually increase by 1.4 to $1.7 \%$. The maximum concentrations of atrazine in river would be raised by 2.5 to $23 \%$. It was also found that the wet season would always take the biggest share of pesticide-loss contribution to the river. A sensitive analysis disclosed that both of streamflow and pesticide concentration are more sensitive to temperature increase than decrease. This study is the first one to quantify the relationship between pesticide loss and climate change through a mathematic modeling system. The results can help people more effectively assess climate-change impacts, manage pesticide practices, and control water pollution.
\end{abstract}

Keywords: climate change, impact assessment, environmental modeling, pesticide loss, runoff, scenario

\section{Introduction}

Agriculture on the North American continent has changed rapidly and continuously since European colonization (Admas et al., 1999). All evidence suggests that agriculture will continue to change rapidly in the future. One of the forces to which future American agriculture will likely have to adapt is changing climate induced by the accumulation of greenhouse gases in the atmosphere (Reilly et al., 2003). Considerable efforts have been made to study the effects of climate change on agricultural systems (Adams, 1990; Adams et al., 1998; Patterson, 1999; GCRP, 2000; IPCC, 2001). However, a number of issues remain unsolved. One issue mentioned as an area in need of further study involves how changes in climate alter pesticide applications and in turn their effects on water quality (Chen and McCarl, 2001). Chained relations exit among climate change, agricultural productivity, pest population, pesticide usage, and pesticide loss. For example, climate change may result in the variance of agricultural productivity and may also lead to pest migration or population expansions. Consequently, pesticide usage (like application rate and frequency) will be adjusted to adapt to these changes, which eventually causes the fluctuations of pesticide loss to ambient water bodies. Furthermore, changed meteorological conditions will disturb pesticide movement processes in the environment, such as emission, volatilization, degradation, and leaching, which also affect pesticide loss.

Although pesticides can greatly increase the quality and quantity of food to feed the growing world population, their

\footnotetext{
* Corresponding author: bingchen@engr.mun.ca
}

losses through surface runoff usually make a significant contribution to the water quality in a watershed with large agricultural fields. Such losses and their potential risks to the public health have got more attention recently (Chen et al., 2003). This is because the chemicals applied as both herbicides and insecticides are long-lived, and can be transported by water. As water runoff moves over the land, pesticides resulting from agricultural activity are picked up and deposited into rivers, lakes, and other bodies of water. Pollutants dissolved in the runoff are generally more biologically available in water bodies than sediment-based fractions and can be potentially more harmful (New York State Department of Environmental Conservation, 1990). It affects human health, quality of life, economic smooth activities, and recreation, as well as the survival of fish and wildlife and ecosystems integral to natural resource preservation (Floyd et al., 1998). For example, Lowe et al. (1991) reported that, nationally, 5\% of fish kills were caused by pesticides in USA. Effective management of them is needed to mitigate adverse environmental impacts associated with pesticide application. As a useful tool to support such management, mathematical modeling plays a key role by simulating the pesticide transport in the environment and predicting the pesticide loss. There were numerous studies on modeling the fate and transport of pesticides in the environment (Floyd et al., 1998; Sauer, 1998; Li et al., 2003a, b; Li and Bidleman, 2003; Chen et al., 2001a, b, 2003, 2004). Some simulation models have been developed and employed to estimate pesticide pollution through surface runoff, such as GLEAMS (Leonard et al., 1987), AGNPS (Young et al., 1986), RZWQM (USDA, 1995), and PeLM (Chen et al., 2003, 2004). However, the previous studies only emphasized on current 
conditions and no one was conducted to predict pesticide loss under climate changing conditions. The complexity of the climate system itself and its relationship to agricultural activities make it difficult to project specific effects on pesticide pollution through simulation models (Admas et al., 1999).

A number of studies have been undertaken to analyze the impacts of climate change on agricultural productions and related activities based on various global change models (Mendelsohn et al., 1994; Admas et al., 1998, 1999; GCRP, 2000; McCarl et al., 2000). Among them, a few studies focused on the influences of future weather on pest population and pesticide usage. For example, Mendelsohn et al. (1994) analyzed subsequent changes in pesticide costs under each climate scenario based on cross-section evidences. Patterson et al. (1999) proposed a deductive approach based on current experience with pest infestation, migration and viability thresholds. They concluded that climate change would shift pest populations since it would alter temperature, precipitation distribution, and wind patterns. Chen and McCarl (2001) employed a regression analysis method to study the interrelationship between pesticide cost and weather, and examined changes in pesticide usage cost for crops, such as corn, cotton, potatoes, and soybeans. Reilly et al. (2003) conducted a latest study on the changes of pesticide expenditure under changing climatic conditions and they concluded that an increase of expenditure would exit in most states but vary with crops in U.S.A. However, no study was found in literature to discuss the impacts of climate change on pesticide loss. It was pointed out by many researchers that the potential environmental implications of changed pesticide use should be addressed in future studies (Admas et al., 1999; Reilly et al., 2003).

The above reviews indicate that it is antouched topic to study the relationship between climate change and pesticide loss. It also becomes an urgent task for researchers to help people more effectively evaluate impacts of climate change on the environment and plan adaptations to associated conesquences. Thus, the objective of this study is targeted to predict the amount of pesticide washed off by surface runoff under changing climatic conditions based on combination of pesticide loss simulation with climate change scenarios. The relationships between pesticide loss and climate change (e.g. temperature and rainfall) will be quantified, which is not available in the current literatures. The objective entails as follows: (a) to develop a modeling system which will combine the pesticide losses model (PeLM) with climate change scenarios, (b) to analyze the impacts of variations of temperature and precipitation on pesticide loss through surface runoff, (c) to apply the proposed method to a real-world case for predicting the pesticide loss in the future (2050 and 2100) under different climate change scenarios, and (d) to examine the possibility of adaptation to climate changes through adjusting pesticide application rate.

\section{Relationship between Pesticide Loss and Climate Change}

The linkages between agriculture and climate are pro- nounced, often complex, and not always well understood (Admas et al., 1999). Correspondingly, the relationship between pesticide loss and climate change becomes more difficult to quantify. The quantity and distribution of pesticide loss are dependent on pesticide usage to crop lands and pesticide movement in the environment. On the one hand, pesticide usage is tightly subjected to agricultural production, which is vulnerable to climate change and involves crop land area, crop types, pest population, tillage practices, and pesticide-application methods, on the other hand, pesticide movement processes, such as emission, wash-off, volatilization, degradation, adsorption, leaching, and runoff, are sensitive to the environmental conditions, especially meteorological conditions (i.e. temperature, precipitation, pressure). Therefore, the impacts of climate change on pesticide loss could be normally classified into two categories: fluctuation of pesticide usage and disturbance on pesticide movement.

\subsection{Fluctuation of Pesticide Usage Caused by Climate Change}

Global climate has changed since pre-industrial times. Atmospheric $\mathrm{CO}_{2}$, a major greenhouse gas, has increased by nearly $30 \%$ and temperature has risen by 0.3 to $0.6{ }^{\circ} \mathrm{C}$. The intergovernmental panel on climate change (IPCC) predicts that with the current emission scenario, global mean temperature would rise between 0.9 and $3.5^{\circ} \mathrm{C}$ by the year 2100 (IPCC, 1996). Temperature increases can have both positive and negative effects on crop yields, with the difference depending in part on location and on the magnitude of the increase. Crop yields in the northern United States and Canada may increase, but yields in the already warm, low-latitude regions of the southern United States are likely to decline. Evidence also suggests positive crop yield effects for mild to moderate temperature increases such as $2^{\circ} \mathrm{C}$ to $3^{\circ} \mathrm{C}\left(3.6^{\circ} \mathrm{F}\right.$ to $5.4^{\circ} \mathrm{F}$ ) (Admas et al., 1999). In one of the most comprehensive studies using three different climate change scenarios and three general circulation models, Rosenzweig and Parry (1994) modeled the impact on wheat, maize, rice and soybean. The crop models were run for changes in $2^{\circ} \mathrm{C}$ and $4^{\circ} \mathrm{C}, \pm 20 \%$ precipitation and for a doubling of $\mathrm{CO}_{2}$. Average crop yields at $2^{\circ} \mathrm{C}$ warming increased by $10 \pm 15 \%$ in wheat and soybeans, and by $8 \%$ in rice and maize. Some adaptations would be conducted with such increases of crop yield, such as changing planting and harvest dates, rotating crops, selecting crops and crop varieties for cultivation, consuming water for irrigation, using fertilizers and pesticides, and choosing tillage practices. Among them, pesticide usage would be adjusted, more possibly be increased based on the study of Chen and McCarl (2001). For example, their study shows that average per acre pesticide usage cost for corn, cotton, potatoes, soybeans and wheat are found to increase as precipitation increases. Similarly, average pesticide usage cost for corn, cotton, soybeans, and potatoes increase as temperature increases. Such increasing pesticide usage would lead to more losses to the environment, especially to ambient water bodies through surface runoff. 
Climate change also affects the trends of precipitation, which cause fluctuation of agricultural production and pesticide loss. For example, increases in precipitation level, timing, and variability may benefit semi-arid and other water-short areas by increasing soil moisture, but could aggravate problems in regions with excess water. While, water content in soil is an important fact to influence a number of pesticide movement processes, which eventually affects pesticide loss. In addition, climate change could alter the frequency and magnitude of extreme events, such as floods, wind storms, and droughts (Admas et al., 1999). It could also change seasonal patterns in both favorable and unfavorable ways, depending on regional conditions. Increases in rainfall intensity pose a threat to agriculture and the environment because heavy rainfall is primarily responsible for soil erosion, leaching of agricultural chemicals (i.e. pesticides), and runoff that carries livestock waste and nutrients into water bodies. However, such negative effects on agro-environmental systems have been largely ignored in climate change assessments. On the other hand, weeds, insects, and pathogen-mediated plant diseases will be affected by global climate change. Alterations in the geographic distribution of these crop pests and their vigor in current ranges likely will occur. Existing research has investigated climatic determinants of the range of many pests, and a large body of literature addresses the effects of warmer drier climates on crops and some their pests (Patterson et al., 1999). Correspondingly, the trends of pesticides application would be adjusted for adapting to such effects. Such adjustment (i.e. increase of pesticide usage) could cause impacts on pesticide loss to the environment eventually.

In terms of weeds, worldwide losses of crop production from weed interference are estimated to be about 12\% (Parker and Fryer, 1975). Extensive efforts are made to control weeds so that over half of the pesticides applied annually to cropland are herbicides for controlling weeds (Furtick and Weeds, 1978). Temperature and precipitation patterns influence the distribution of weeds concurrently with the selection of crops. Weeds will benefit from the " $\mathrm{CO}_{2}$ fertilization effect" and from improvements in water use efficiency associated with the partial closure of stomata by increasing $\mathrm{CO}_{2}$ concentrations (Patterson et al., 1999). The range expansion of many weeds into higher latitudes may accelerate with global warming (Patterson et al., 1993). For example, a $3{ }^{\circ} \mathrm{C}$ warming of California areas would effectively shift the itchgrass (Rottboellia cochinchinensis Lour.) zone of growth northward. Increasing $\mathrm{CO}_{2}$ and climate change probably will require modification of current weed control technology (Patterson et al., 1995). Environmental factors such as temperature, precipitation, wind, soil moisture, and atmospheric humidity influence the application of herbicides and their effectiveness (Hatzios and Penner, 1982). For example, temperature and moisture availability affect both the uptake and metabolism of herbicides by crops and target weeds. The antitranspirant effects of higher $\mathrm{CO}_{2}$ levels could reduce plant uptake of soil-applied herbicides. In terms of insects, climate change will affect the distribution and degree of infestation of insect pests through both direct effects on the life cycles of insects and indirectly through climatic effects on hosts, predators, competitors, and insect pathogens. For example, there is some evidence that the risk of crop loss will increase due to poleward expansion of insect ranges (Southwood and Comins, 1976). Intense precipitation has been noted as a deterrent to the occurrence and success of oviposition by insects such as the European corn borer (Ostrinia nubilalis) (Davidson and Lyon, 1987). One principal concern is that global warming can increase their population size by undergoing and extra generation each year in warmer climates or expand their geographical distributions. It could also facilitate overwintering of insect populations and favour earlier poleward migrations in the spring (Patterson et al., 1999). Based on these predictions, more adaptations of insecticides application, such as improving efficiency and increasing quantity, would be conducted to control the negative effects. Correspondingly, more pesticide residues will be available for carrying out by surface runoff, sediment transport, or downward leaching processes. In terms of plant diseases, they may cause severe reduction in plant growth and further restrict the limited range of crops/cultivars that are adapted to a changing climate (Chakraborty et al., 2000). Usually, the occurrence of plant fungal and bacterial pests depends on temperature, rainfall, humidity, radiation, and dew. Climatic conditions affect the survival, growth and spread of pathogens as well as the resistance of their hosts to infection. For example, Meier (1985) found that mild winters have been associated with more rapid and stronger outbreaks of powdery mildew (Erysiphe grammis). Warmer, humid conditions lead to earlier and stronger outbreaks of late potato blight (Phytophthora infestans) (Parry et al., 1990). More new pesticides and effective practices would be desired, which cause potential risks to the environment. The challenges to protect agriculture from pests probably, as well as to prevent the environment pollution from pesticides loss, will increase.

\subsection{Disturbance on Pesticide Movement Caused by Cli- mate Change}

Pesticide movement in the environment involves a number of dominant processes (Figure 1), which are the causes of pesticide loss. Meanwhile, such processes are subjected to the conditions of ambient environment including the changes of climate.

Pesticide emission is the releasing process of pesticides into the air from agricultural fields. Following pesticide application to agricultural lands as spray or soil incorporation, the pesticide particles are emitted from plant canopy or soil surface to the atmosphere. The emission amount of pesticide usually depends on the vapor pressure and heat of vaporization of the chemicals, the partition coefficient between the atmosphere and any other phase, and the air flow mass which will transport the airborne chemicals (Freed and Haque, 1973). Wash-off - Pesticides applied on leaves or crop residues are subject to interception by the plant material. These pesticides remain on the plant surface until they are removed by intercepted rainfall or volatilize (Willis et al., 1986). The wash-off of these pesticides will amend the pesticide load in the soil 


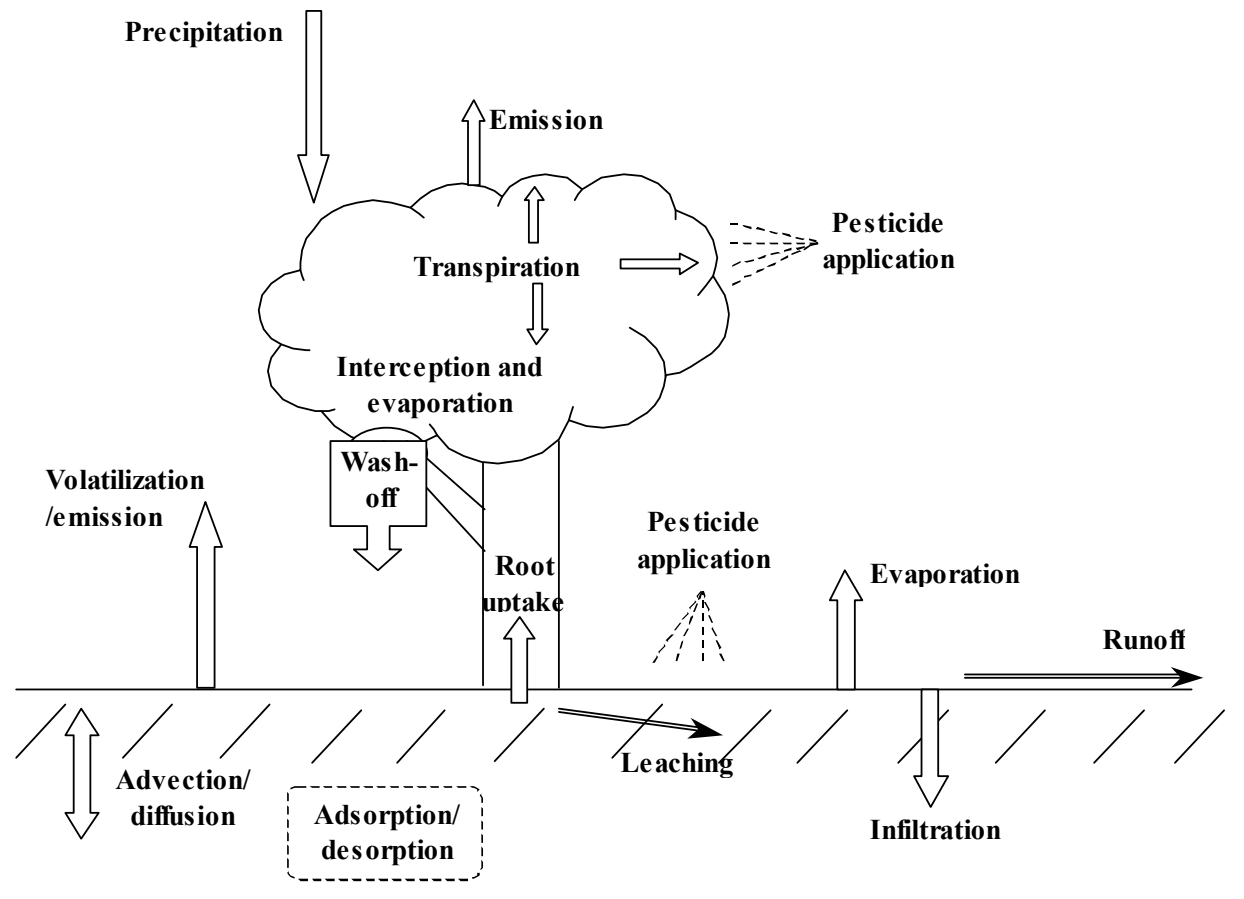

Figure 1. Diagram illustrating processes of pesticide movement.

and thus will alter the amount of pesticide available for movement by runoff and sediment. The wash-off amount of pesticides is especially affected by rainfall duration and intensity. Adsorption/desorption - Pesticide molecules in soils can be adsorbed/desorbed by soil particles. Adsorption refers to the adhesion or attraction of the ions or molecules to the soil particles' surface. The degree of adsorption-desorption between the soil and the pesticide influences the bioactivity, leachability, and degradability of these chemicals in a given environment, and affects their distribution through the soil profile (Wauchope and Myers, 1985). This process is affected by soil characteristics such as organic matter content, $\mathrm{pH}$, soil particle size distribution, temperature, and moisture content. Volatilization - It refers to the diffusion of pesticides through the soil to the soil surface and the movement of a pesticide into and through the atmosphere (Azevedo, 1998). Volatilization of pesticides is dependent on the vapor pressure and heat of vaporization of the chemical, the partition coefficient between the atmosphere and any other phase, and the air flow mass which will transport the airborne chemical. Leaching Pesticide leaching through soil is an environmental concern because of the possibility that they will reach the water table and contaminate the ground water. Two different pathways are normally dominant for pesticide leaching through the soil profile: with the water into the soil matrix, and through macropores (Hamaker, 1975). This process is affected by various factors, such as pesticide retaining time in the top soil, soil types and properties, preferential flow, tillage activities, water content. Surface runoff - Pesticides carried by surface runoff from agricultural areas constitute a significant portion of the pesticide pollutant loading rates to surface water bodies. A pesticide molecule during the transport can exist either in the dissolved phase or in a solid phase associated with a soil particle or colloid (Larson et al., 1997). Such transport depends on the form in which the compounds exist in the water, the hydrodynamics of the watershed system, and meteorological conditions. Degradation - This process refers to the breakdown of pesticides by photochemical, chemical, and microbial decomposition within the environment. Biological degradation, which is the result of microbial metabolism of pesticides, is often the main source of pesticide degradation in soils (Freed and Haque, 1973). Soil organic matter content, moisture, temperature, aeration, and $\mathrm{pH}$ all affect microbial degradation. Plant uptake - The experiments have proved that pesticides can enter the plant issues and are found in foods (Kaufman, 1983). Such process is called plant uptake, which is affected by many factors. The most important factors are the plant species, growth stage, and intended use. Soil characteristics such as $\mathrm{pH}$, temperature, clay fraction, moisture content, and particularly organic matter content also influence the uptake of pesticides by plants (Finlayson, 1973).

The above discussion shows the pesticide loss (or transport) can be affected by the environmental conditions, such as soil moisture, $\mathrm{pH}$, organic matter content, ambient temperature, precipitation, vapor pressure. The variances of these factors are all subjected to the change of meteorological conditions. Generally, climate change has significant impacts on pesticide movement processes, which will eventually influ- 
ence the quantity and distribution of pesticide loss.

\section{Climate Change Scenarios and Numerical Simulation}

\subsection{Climate Change Scenarios}

Emissions scenarios provide an important input for the assessment of future climate change (IPCC, 2000). Future anthropogenic GHG emissions depend on numerous driving forces, including population growth, economic development, energy supply and use, land-use patterns, and a host of other human activities. The simulation scenarios used in this study are based on the IPCC SRES (Special Report on Emission Scenarios) B2 scenario. The B2 scenario should represent a world in which the emphasis is on local solutions to economic, social and environmental sustainability. This scenario is based on the IPCC IS92a scenario, which specifies equivalent greenhouse gas (GHG) concentrations and sulphate aerosol loadings from 1850 to 2100 (CCCma, 2004). Climate change simulations based on this scenario have been performed by a number of climate modeling groups who have contributed to the IPCC Third Assessment Report. The IPCC SRES provides 40 different scenarios which are deemed "equally likely". For the Third Assessment Report, the IPCC facilitated the conversion of two of these emission scenarios (A2 and B2) into concentration scenarios for use in climate simulations. The A2 scenario envisions population growth to 15 billion by the year 2100 and rather slow economic and technological development. It projects slightly lower GHG emissions than the IS92a scenario, but also slightly lower aersol loadings, such that the warming response differs little from that of the earlier scenario. The B2 scenario envisions slower population growth ( 10.4 billion by 2100 ) with a more rapidly evolving economy and more emphasis on environmental protection. It therefore produces lower emissions and less future warming (CCCma, 2004). The B2 scenario produces a more modest warming compared to the "IS92a" and "A2" scenarios (Figure 2). This study selects it to examine the future pesticide pollution under the most conservative scenario or optimistic climate-change conditions.

To examine the possibility of adaptation to climate changes through adjusting pesticide application rate, pesticide loss prediction under different scenarios were conducted. According to the study by Reilly et al., 2003), the increase of pesticide expenditure under changing climatic conditions is 10 to $20 \%$ on maize, 5 to $15 \%$ on potatoes, 2 to $5 \%$ on cotton and soybean, and -15 to $+15 \%$ on wheat in United States. Thus, 10 and $20 \%$ of increase for pesticide usage are assumed in 2050 and 2100, respectively. Therefore, the three simulation scenarios were set based on the IPCC SRES B2 scenario (Table 1). Because of the long time horizons involved in climate change assessments and uncertainties concerning the rate at which climate will change, it is difficult to quantify the interactions among climate conditions, soil properties, agricultural production, pesticide usage, and pesticide loss in the future. In current stage, this research employs two assumptions to simplify the study system: (a) neglecting the changes of soil properties like soil moisture caused by climate changes, and (b) neglecting the changes of growing seasons and the movement of the limits of crops growth. In addition, another assumption should be set for considering no new or modified pesticides involved through the simulation periods.

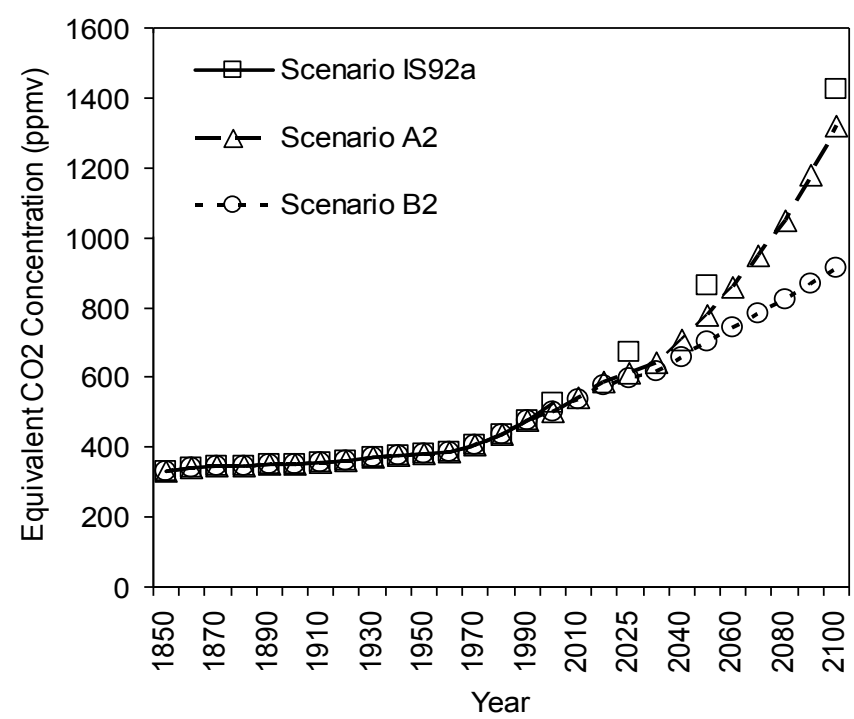

Figure 2. Equivalent $\mathrm{CO} 2$ concentration (ppmv) under Scenarios IS92a, A2, and B2 (CCCma, 2004).

Table 1. Simulation Scenarios

\begin{tabular}{|c|c|c|c|}
\hline \multirow[t]{2}{*}{ Scenario } & \multirow[t]{2}{*}{ Climate change } & \multicolumn{2}{|c|}{ Pesticide usage } \\
\hline & & 2050 & 2100 \\
\hline $\mathrm{I}$ & $\begin{array}{l}\text { IPCC SRES B2 } \\
\text { scenario }\end{array}$ & $\begin{array}{l}\text { No change } \\
\text { (using average } \\
\text { usage of } \\
1990-2002 \text { ) }\end{array}$ & $\begin{array}{l}\text { No change } \\
\text { (using average } \\
\text { usage of } \\
\text { 1990-2002) }\end{array}$ \\
\hline II & $\begin{array}{l}\text { IPCC SRES B2 } \\
\text { scenario }\end{array}$ & $5 \%$ increase & $10 \%$ increase \\
\hline III & $\begin{array}{l}\text { IPCC SRES B2 } \\
\text { scenario }\end{array}$ & $10 \%$ increase & $20 \%$ increase \\
\hline
\end{tabular}

\subsection{Modeling Formulation}

The pesticide loss model (PeLM) developed by Chen et al. $(2003,2004)$ was employed to predict the pesticide losses through runoff from agricultural lands. The model is an integration of a mathematical model and a geographic information system (GIS). The model not only insures adequate prediction of hydrologic response and pesticide fate and transport, but also is modest in data requirements. It also incorporates GIS and relational database management system to facilitate the spatial data organization.

The model is an integration of a mathematical simulation model and a GIS, which accounts for the transport of pesticide and its spatial distributive characteristics. The simulation model consists of six modules: (a) hydrology module, to calculate the volume of runoff, (b) pesticide wash-off module, to simulate the pesticide wash-off from crop canopy and surface 
residue, (c) pesticide adsorption/desorption module, to describe the adsorption/desorption process in the mixing soil layer, (d) pesticide concentration available for runoff, to calculate the pesticide concentration available in the soil for runoff, (e) pesticide sediment module, to calculate the pesticide concentration in sediment leaving the field by runoff, and (f) pesticide routing module, to route the pesticide during runoff using a continuity equation. In the GIS integration model, the pesticide runoff model was combined with a database and a GIS. Based on the specific GIS software, some necessary parameters that were used in pesticide runoff model, such as slope, aspect and flow-direction, could be obtained through spatial analysis. To reflect the spatial distribution, the watershed is conceptually divided into a number of grid cells. Each cell can be treated as a unit for pesticide behaviours with inflows from and outflows to other grid cells. The spatial data from GIS and remote sensing (RS) studies, combined with related pesticide properties and soil characteristics, are combined into the grid system and stored in the database for modeling the pesticide losses. The database can not only store the initial and final data, but format the raw data and transfer them between the GIS model and simulation model. The final results can be presented graphically in the GIS model. The detail formulations of PeLM can be found in Chen et al. (2003, 2004).

\section{Study Area and Data Acquisition}

\subsection{Overview of the Study Area}

The Auglaize-Blanchard Watershed (Latitude: $40.49^{\circ} \sim$ 41.28 , Longitude: $-83.38^{\circ} \sim-85.01^{\circ}$ ) is located in northern Ohio, USA (Figure 3). It contains two adjacent sub-basins. The western portion is the Auglaize River Sub-Basin and the eastern one is the Blanchard River Sub-Basin. The length of the Auglaize River is $163 \mathrm{~km}$, with the river basin covering an area of $6,234 \mathrm{~km}^{2}$. The Blanchard River extends $146 \mathrm{~km}$, with its basin covering $1,974 \mathrm{~km}^{2}$.

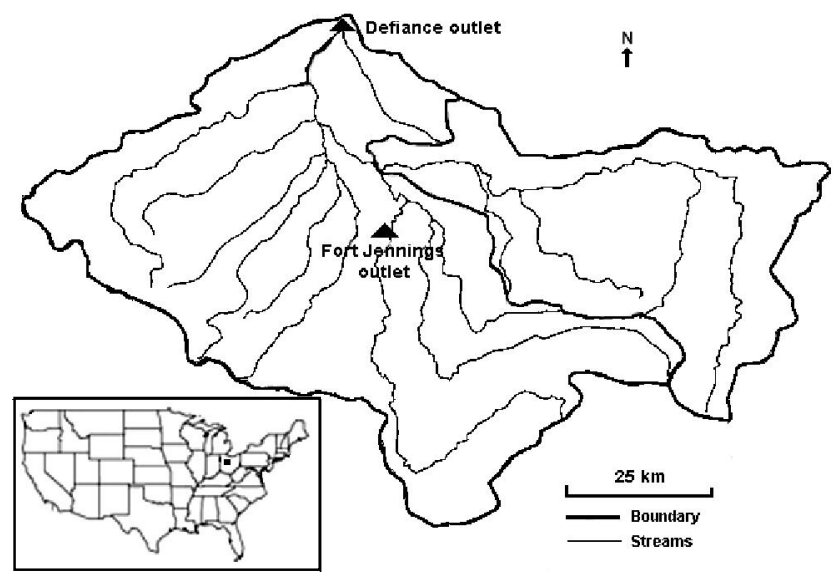

Figure 2. The study area.

The watershed comprises a flat lake plain in the center, and sloping till plains around the edges. The U.S. Department of Agriculture (USDA, 1993) reported the average slope of $0.61 \mathrm{~m} / \mathrm{km}$ for the Auglaize River and $0.17 \mathrm{~m} / \mathrm{km}$ for the Blanchard River. Sand and gravel are present as discontinuous deposits in the river valleys as well as the western part of the basin. Annual precipitation between 1990 and 1998 in the Auglaize-Blanchard Watershed ranged from $853.4 \mathrm{~mm}$ (Paulding County) to $932.2 \mathrm{~mm}$ (Van Wert County). Rainfall peaks in May or June, while the lowest precipitation occurs in January or February. In this watershed, about $75 \%$ of the land is for agricultural uses while $10 \%$ for forest. The study area lies in the eastern U.S. Corn Belt (Hess, 1995). The major crops are corn, soybeans, wheat, oats, and alfalfa (hay). Other agricultural land uses include pasture and forage crops (USGS, 2000).

An index of watershed indicators (IWI) proposed by the USEPA (USEPA, 2002) was utilized to describe the health of the aquatic resources in this watershed. The Auglaize River Basin scored 5 which represents the level of "more serious water quality problems" -- "High Vulnerability" to stressors such as pollutant discharges. The Blanchard River Basin got a score of 3, which indicates "less serious water quality problems" - "Low Vulnerability" to stressors. Nonpoint source pollutions including pesticide loss have been one of the most serious environmental problems in Ohio. Pesticide applications to crop lands are among the highest nationwide. The five most heavily applied agricultural pesticides are metolachlor, atrazine, cyanazine, acetochlor, and alachlor. Among them, atrazine, which is the target of this study, has been found in every streams and its pollution problem acquired more attention recently.

\subsection{Data Acquisition}

For the verification part, the precipitation and temperature data are obtained from the dataset of NOAA (National Oceanic \& Atmospheric Administration), NCDC (National Climatic Data Center) DAILY FSOD (USNOAA, 2003). Station 14825 at the Findlay Airport, Ohio was selected for this study. Its data cover the period between 1990 and 1998. Two concerned outlets located in the area have been selected: Fort Jennings that is the outlet at the center of the watershed, and Defiance that is the outlet of the entire watershed. Runoff simulation was conducted to provide basis for estimating atrazine loss. An accurate simulation of runoff volume would render reliability of atrazine-loss estimation. The stream flow data came from the National Water Information System of USGS. Two stations located in the study area were selected: USGS Station 04186500 at Fort Jennings, Ohio and USGS Station 04191500 at Defiance, Ohio. The monitoring dates ranged from 1990 to 2001. The information about the observed atrazine concentrations was acquired from the USGS Water Quality Sample Site at Fort Jennings. Eleven sets of the observed atrazine concentrations as obtained from monitoring programs during May 1997 and June 1998 were available for verifying the developed model. Gridded atrazine usage (1990 to 1998) in the United States was estimated from the data 
provided by the U.S. Geological Survey (USGS) Pesticide National Synthesis Project, while that in Canada was from Environment Canada ( $\mathrm{Li}$ et al., 2003b). The raw data of soil properties, such as bulk density, organic-matter content, and soil hydrology group, were acquired from STATSGO - State Soil Geographic Data Base organized by USGS (USDA, 1991). For the prediction part, the precipitation and temperature data are obtained from the Data obtained through CGCM2 (Canadian Global Coupled Model v.2) developed by Canadian Centre for Climate Modelling and Analysis (CCCma). The CCCma is a division of the Climate Research Branch of the Meteorological Service of Canada of Environment Canada. The data were extracted from the simulation results using CCCma coupled global climate model (CCCma, 2004).

The digital elevation model (DEM) data of the study area were obtained from the DEM STATUS GRAPHICS Dataset of USGS. The 7.5-minute DEM dataset casts on the UTM projection system referenced to the North American Datum of 1927 (NAD 27) (USGS, 2004). The dataset is stored as profiles with a 30 -meter square grid spacing along and between each profile. The DEM datasets were used to generate basic hydrological inputs for the pesticide loss model. Several parameters, such as flow accumulation, aspect, and slope, were derived by using ArcView 3.2 GIS $\AA$. In this study, a $10 \mathrm{~km} \times$ $10 \mathrm{~km}$ (or $1 / 12^{\circ} \times 1 / 8^{\circ}$ latitude-longitude) grid system was created for the distributed modeling system. For each grid cell, the following parameters were acquired: latitude and longitude coordinates for each grid centroid, predominant soil type, soil bulk density, organic matter, land-use type, SCS curve number, total atrazine-application amount, atrazine-application efficiency, the first atrazine-application date (and percenttage of application amount), and the second atrazine-application date (if any, as well as percentage of application amount).

\subsection{Model Verification}

In the Great Lakes Basins, atrazine is usually applied in May by spray and soil incorporation. A period between May 1996 (right after pesticide application) and April 1997 was selected for simulating the fate of atrazine in the AuglaizeBlanchard Watershed through the pesticide runoff model. Atrazine concentration $(\mu \mathrm{g} / \mathrm{L})$ in the river was used for analyzing the pollution conditions. The mass flux of atrazine could then be estimated based on the predicted concentrations and the total water discharge. The modeling results of runoff and atrazine concentration under different time scales were obtained and then compared with the observed data whenever they are available. The details are reported in the "Appendix: Supporting Information".

\section{Results and Discussion}

\subsection{Pesticide Loss Prediction}

Using the proposed model, the pesticide losses through surface runoff from the study watershed were predicted under three scenarios. Figures $4 \mathrm{a}$ and $4 \mathrm{~b}$ show that the plots of daily precipitation and maximum temperature for three time periods,
1996 to 1997, 2049 to 2050, and 2099 to 2100 . The history data were obtained from the weather station at the Findlay Airport, Ohio. The future daily meteorological data were extracted from CGCM2 developed by CCCma under IPCC SRES B2 scenario. In terms of precipitation, the annual value would increase by $14 \%$ in 2050 and $9 \%$ in 2100 . Based on the 30 -year historical data in the study area, May and June have the highest monthly precipitation. Such wet seasons for the three time periods would be still stick to the same period (May to June), where approximately 21 to $25 \%$ of total precipitation occurs. However, the rainfall would be scattered lightly. For example, there would be highest rainfall in fall instead of in spring during 2049 to 2050 . It could be good for lowering pesticide-pollution risks during planting season for pesticide losses are much subjected to rainfall intensity. In terms of temperature, there is a trend of gently elevation in the future. The weather in the study area would become warmer by 0.2 to $2.65{ }^{\circ} \mathrm{C}$ within 100 years. The hot days with over $30^{\circ} \mathrm{C}$ would be increasing from 36 to 48 in 2050 and 61 in 2100. Meanwhile, the winter period would be shrinking. The freezing days with temperature below $0^{\circ} \mathrm{C}$ during 1996 to 1997 are 54, while, the numbers for 50 and 100 years later would be 37 and 17, respectively. A shorter winter indicates more snowmelt leading to larger surface runoff, which could remove more pesticide residues from crop lands, on the other hand, more snowmelt causing larger flow volume, which could dilute pesticide concentrations in the river water.

Figure $4 \mathrm{c}$ shows that the plot of daily streamflow at the Defiance outlet for three time periods, 1996 to 1997, 2049 to 2050 , and 2099 to 2100 . The annual average streamflow would increase by 3 to $5 \%$ within 100 years for the elevation of precipitation. The river channel would carry out more water in 2050 than that in 2100. In comparison, peaks of streamflow always follow after peaks of precipitation with a time lag, which results from the process of surface runoff transport. For example, the highest rainfall $(3.76 \mathrm{~cm})$ during the year would be found on June 11, 2100, and a week later, the highest streamflow $\left(374 \mathrm{~m}^{3} / \mathrm{s}\right)$ would occur at the Defiance outlet. Considering the washing off function of rainfall to the pesticide residues, it will take highest risk of river pollution to apply pesticides during high-rainfall season. During the wet season (May to June), intensive rainfall leads to a high level of streamflow for all the three time periods. During the dry (or winter) season, the melt snow caused by warmer weather keeps the channel being charged with a relatively high water flow, especially in the winter of 2100.

Figure $4 \mathrm{~d}$ shows that the trend of daily atrazine concentration in the river water at the Defiance outlet for three time periods. The results for 2050 and 2100 were generated through the proposed model under Scenario III. The concentrations decreased significantly with time due to the natural attenuation. The maximum concentration would gradually increase from $1.11 \mu \mathrm{g} / \mathrm{L}$ on May 14,1996 to $1.81 \mu \mathrm{g} / \mathrm{L}$ on May 19, 2050 and $2.03 \mu \mathrm{g} / \mathrm{L}$ on May 12, 2100. They are all lower than the maximum allowable contaminant level of $3.0 \mu \mathrm{g} / \mathrm{L}$ as regulated in the water quality criteria (3745-1-34) under the "Safe Drinking Water Act" of Ohio (Ohio Environmental Pro- 

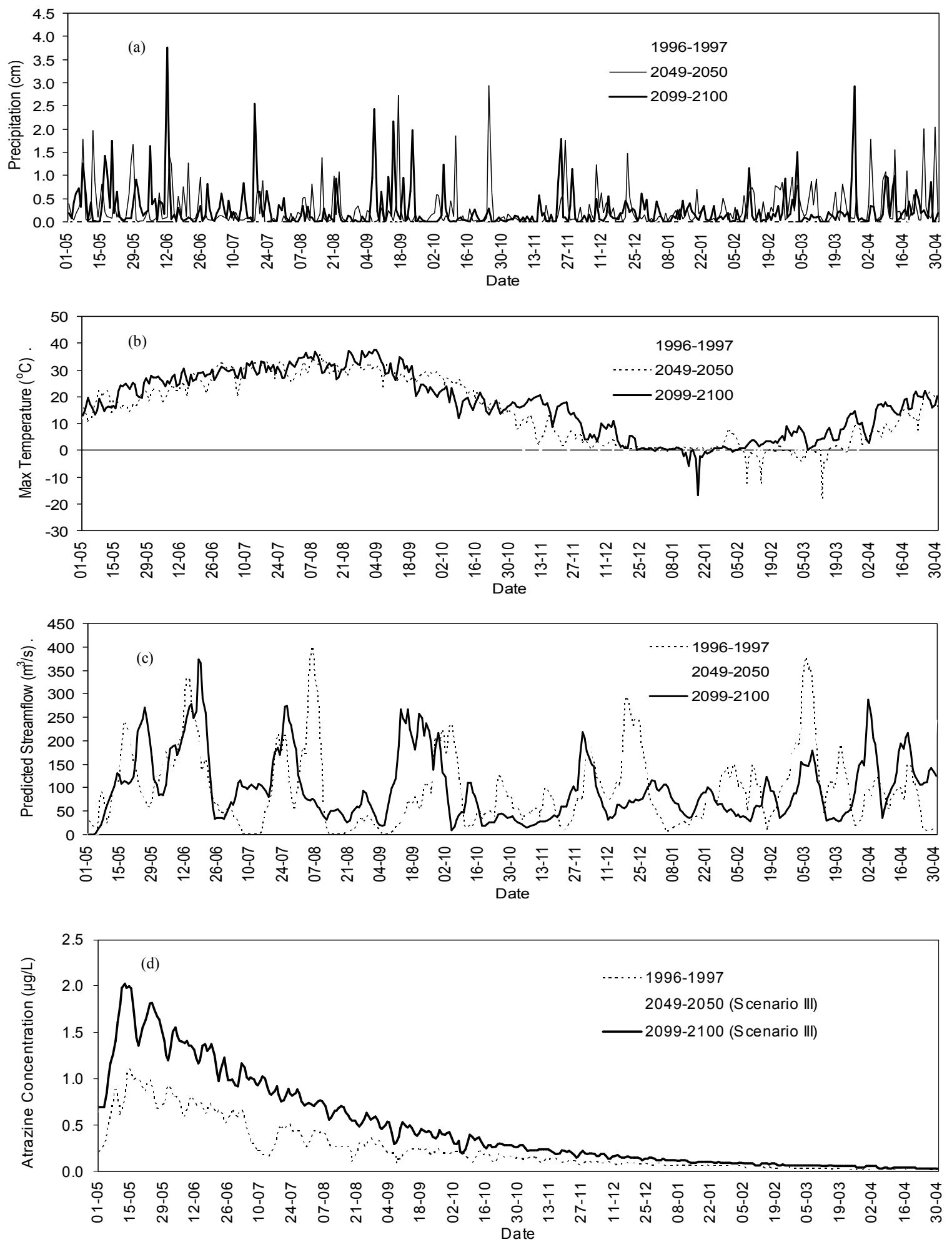

Figure 3. Comparison of daily (a) precipitation, (b) maximum temperature, (c) streamflow, and (d) atrazine concentration at the Defiance outlet. 

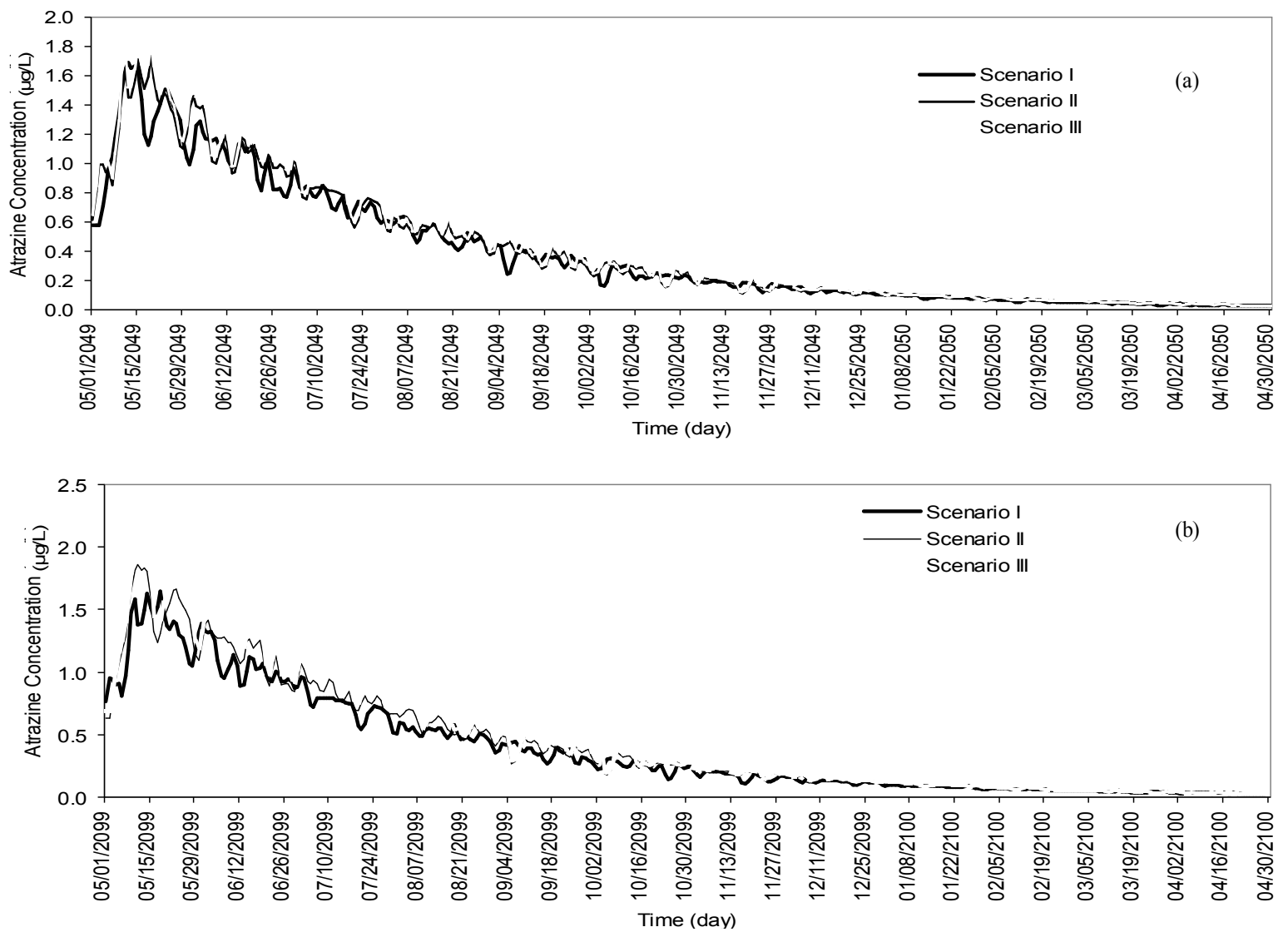

Figure 4. Daily atrazine concentration at the Defiance outlet (a) during 2049 to 2050 and (b) 2099 to 2100 under three scenarios.

tection Agency, 2002). However, the assumption that the criteria will not be changed within 100 years seems not reasonable with the inevitable elevation of requirements for environmental quality. Furthermore, the climate change scenario, IPCC SRES B2, is the most conservative one among the 40 scenarios provided by IPCC. The atrazine pollution under the three scenarios would be the best situation if compared with the prediction results conducted under other IPCC scenarios.

As discussed above, the pesticide losses are subjected to a number of factors, such as meteorological conditions, soil properties, pesticides characteristics/application methods. The impacts caused by climate change on pesticide loss would depend on two ways: fluctuation of usage amount and disturbance on movement process. Pesticide usage varies by crop, region, and year. Changes in local conditions and climate, as manifest in changes in pest population and incidence, alter the total cost of pesticide usage, the mixture of compounds employed and the application rates for any given crop. Furthermore, the pattern of precipitation and temperature will also affect the pesticide movement processes through changing runoff volume, river flow speed, degradation rate, etc. Thus, pesticide loss would be different based on variations of scenarios. The possibility of adaptation to climate changes through adjusting pesticide application rate was examined through the case study. Figure 5 shows that the trend of daily atrazine concentration in the river water at the Defiance outlet under three scenarios in the future. During May 2049 to April 2050, the atrazine losses would increase with the elevation of pesticide usage (Figure 5a). For example, the 5\% and $10 \%$ augment of atrazine usage in 2050 would raise the maximum concentrations by $2.5 \%$ and $7.4 \%$, respectively. Similarly, the atrazine losses would be also increased with more atrazine applied during May 2099 to April 2100. The maximum concentrations would be elevated by $13 \%$ and $23 \%$ with $10 \%$ and $20 \%$ augment of atrazine usage during such period, respecttively.

To examine the total losses of atrazine from crop lands, the mass fluxes of atrazine were estimated based on the predicted concentrations and the total water discharge. The monthly values under different scenarios were shown in Figure 6. The results indicated that over $8 \%, 9.4 \%$, and $9.7 \%$ of total applied atrazine would be removed through surface runoff from crop lands under the Scenario I, II, and III, respectively. The wet season (May to June) would always take the biggest share of pesticide-loss contribution to the river. For example, approximately $60 \%$ of the total atrazine losses would occur during such season under the Scenario II in the period of May 2049 to April 2050. Similarly, such season would be also 
responsible for approximately $58 \%$ of the total atrazine losses under the Scenario II in the period of May 2099 to April 2100. Therefore, the regions, like Great Lakes Basins, where atrazine is usually applied in May by spray and soil incorporation, would face to a more and more serious atrazine pollution problems if no adaptations were conducted in the future. The employment of appropriate approaches, such as reducing application rate, using post-emergency application, and improving tillage methods, in the study areas would help control atrazine loss and mitigate related pollution.
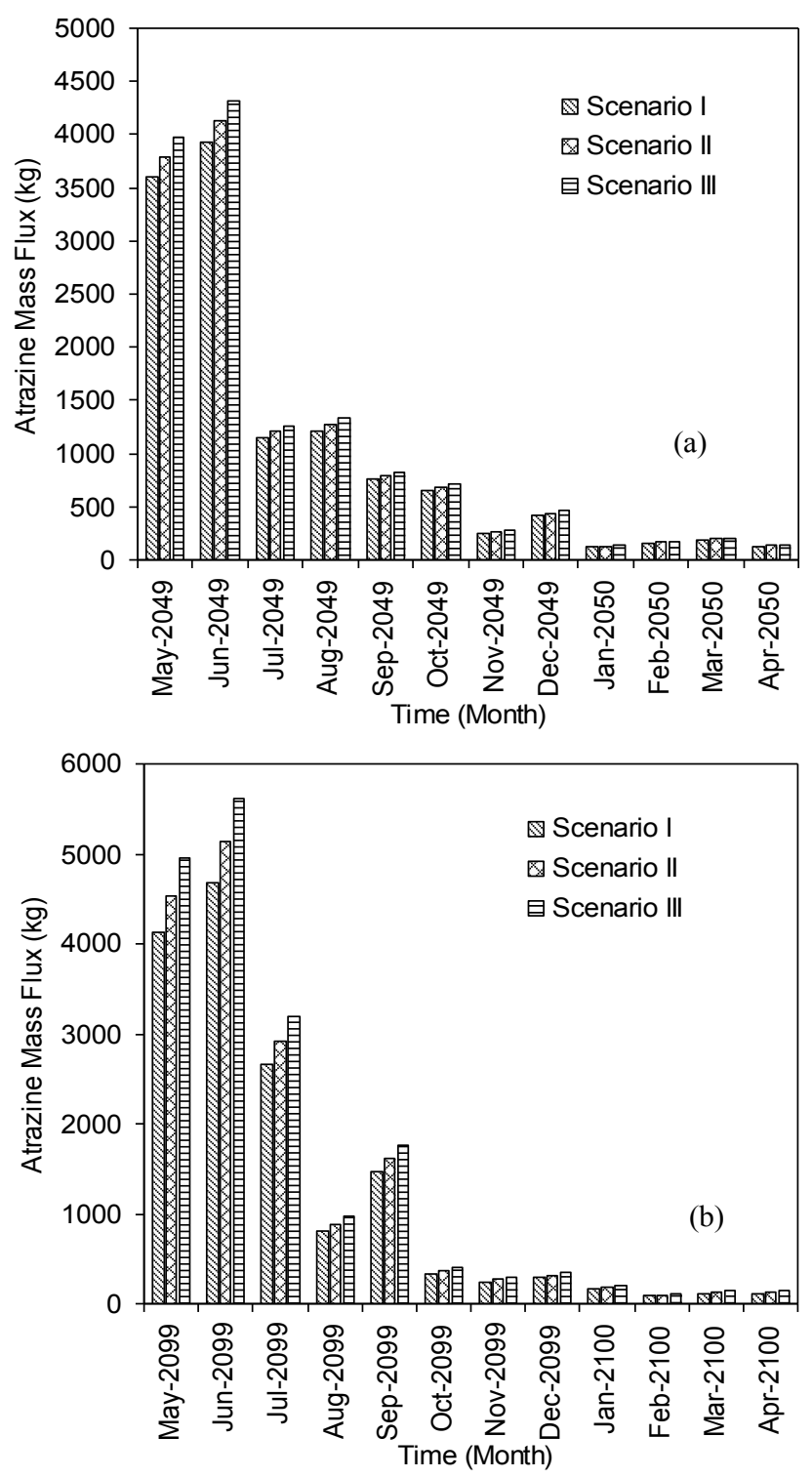

Figure 5. Modeling results for monthly atrazine mass flux at the Defiance outlet (a) during 2049 to 2050 and (b) 2099 to 2100 under three scenarios.

\subsection{Sensitivity of Pesticide Loss to Variations of Tempera- ture and Precipitation}

To examine the impacts of climate change on pesticide loss, the sensitivity of model output to variances of model input parameters (see "Appendix: Supporting Information") and climate conditions were conducted using proposed model. The fluctuations of streamflow and pesticide concentration were observed based the variations of two meteorological parameters, temperature and precipitation. Figure 7a shows the sensitivity of streamflow variation of $\pm 1{ }^{\circ} \mathrm{C}$ change on temperature and $\pm 1 \%$ change on precipitation. The results indicate that streamflow is more sensitive to temperature increase than decrease, with an average elevation of $6.4 \%$. However, the maximum elevation reaches $309 \%$, which occurs in November. During the winter, one-degree temperature increase leads to approximately $15.4 \%$ elevation on streamflow in the study watershed. Meanwhile, temperature decrease would also affect the streamflow although its sensitivity to the decrease is lower than the increase with an average decline of $3 \%$. These results disclose a key role of snow played in the hydrological cycle. For snowmelt is one of the major water resources for the local river flow, it would be significantly influenced by fluctuation of temperature, especially the increase. On the other hand, streamflow is also sensitive to precipitation variations. The $+1 \%$ increase and $-1 \%$ decrease of precipitation would cause maximum $3.9 \%$ elevation and $3.8 \%$ decline of streamflow, respectively.

Figure $7 \mathrm{~b}$ shows the sensitivity of pesticide concentration variation of $\pm 1{ }^{\circ} \mathrm{C}$ change on temperature and $\pm 1 \%$ change on precipitation. The results indicate that pesticide concentration is more sensitive to temperature increase than decrease. The fluctuation of pesticide concentration is quiet large and ranges from -9 to $25 \%$ with one-degree temperature increase. Meanwhile, such fluctuation is relatively small with a range of -0.2 to $0.4 \%$ with one-degree temperature decrease. The maximum changes of pesticide concentration occur in winter, which indicated that snowmelt is also critical to pesticide pollution through changing the streamflow volume. On the other hand, pesticide concentration is also sensitive to precipitation variations. On the other hand, streamflow is also sensitive to precipitation variations. For pesticide concentration in the river water depends on multiple factors, such as the amount of pesticide losses from crop lands, flow volume, degradation (related to half-life and time). The flow volume, one the most important factors, would be directly influenced by the variations of precipitation, which could be indicated by Figure $7 \mathrm{a}$. The augment of flow volume will dilute the pesticide concentration, so that the decline of pesticide concentration would occur with increase of precipitation. Actually, the results show that the $1 \%$ increase of precipitation would cause maximum $0.02 \%$ elevation and $0.04 \%$ decline of concentration, the $1 \%$ decrease of precipitation would cause maximum $0.04 \%$ elevation and $0.02 \%$ decline of concentration.

\section{Conclusion}

This study attempted to analyze and predict the impacts of climate change on pesticide pollution through a mathematical simulation model. An integrated modeling system which combined a distributed pesticide loss model with geo- 
graphic information system (GIS), database, and climate change scenarios was developed. It can simulate the pesticide movement processes, such as wash-off, degradation, adsorption, surface runoff, and sediment transport. A case study conducted in the Auglaize-Blanchard Watershed, northern Ohio, was used to validate the proposed system and the results indicated a satisfactory accuracy of simulation.
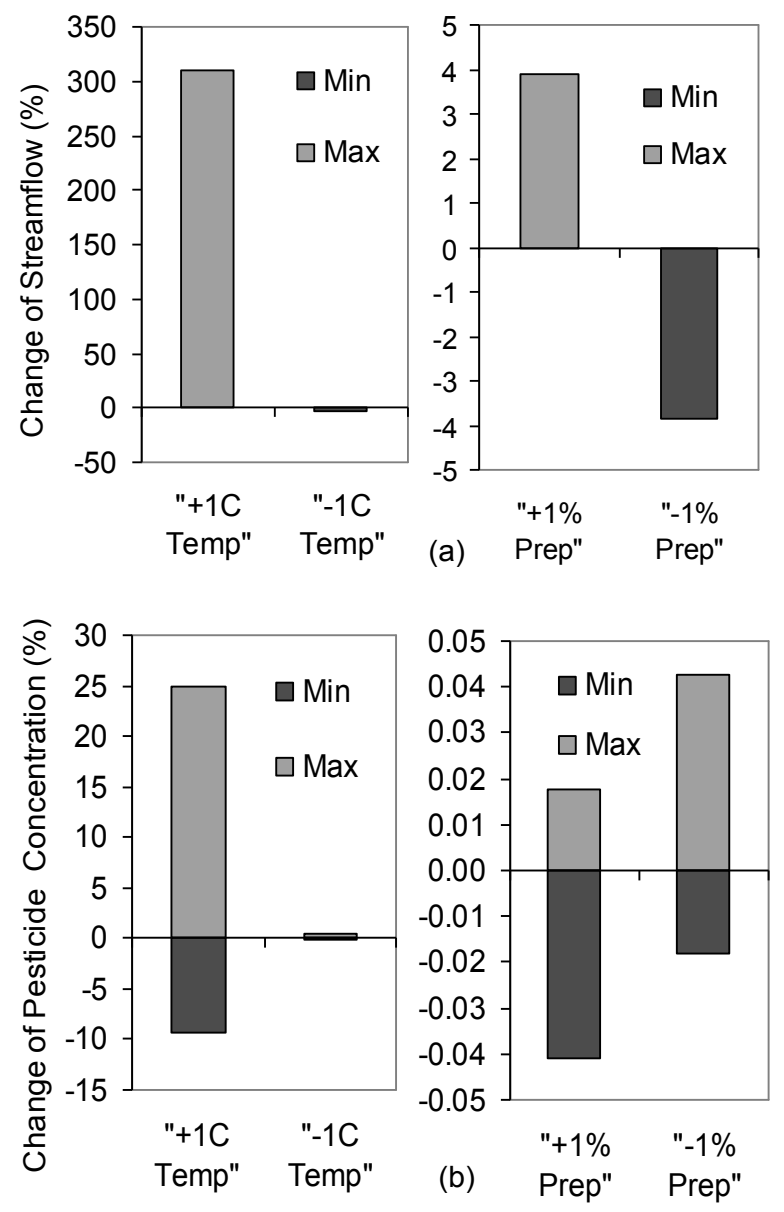

Figure 6. Sensitivity of (a) streamflow and (b) pesticide concentration variations of temperature and precipitation.

The modeling system was then applied to predict the pesticide loss in the future (2050 and 2100) under different scenarios. The results indicated that the elevation of precipitation and temperature would result in the gradually increase of streamflow and atrazine loss. Under the three scenarios, the atrazine concentrations in river water would increase along with augment of pesticide usage and approach to the standard. It was found that the wet season (May to June) would always take the biggest share of pesticide-loss contribution to the river, which implies that the risk of river pollution caused by applying pesticides during such a season would be highest. It also disclosed that both of streamflow and pesticide loss are more sensitive to temperature increase than decrease. Meanwhile, they were also changed in various ranges with the fluc- tuation of precipitation trends.

This study is among the first ones to quantitatively reveal the relationships between climate change and pesticide loss through a mathematic modeling system. The system could not only tell the impacts of elevation of temperature and precipitation on pesticide loss, but also predict the future situation of pesticide pollution under changing climatic conditions. The results could help people get insight of the effects of global warming on the environment and make more efficient decisions in pesticide practice and watershed management. In addition, the system could also support adaptation planning in mitigation of pesticide pollution under changing climatic change.

However, some prediction errors exist inevitably owing to the uncertainties of the input data (i.e. meteorological data extracted from GCM). Increasing the certainty of the data sets through further investigation and high-resolution RCM employment would help increase the prediction accuracy. In addition, considering the complexities of the study system, several assumptions were employed, such as neglecting the variances of soil properties, growing seasons, and pesticide types along with climate change. These assumptions would weak the feasibility of the proposed system, which will be improved in the future study.

Acknowledgments. This work was supported by the Major State Basic Research Development Program of MOST (2005CB724201 and 2006CB403307) and Environment Canada.

\section{References}

Adams, R.M., Hurd, B.H., Lenhart, S., and Leary, N. (1998). Effects of global climate change on agriculture: an interpretative review, Clim. Res., 11, 19-30.

Adams, R.M., Rosenzweig, C., Peart, R.M., Richie, J.T., McCarl, B.A., Glyer, J.D., Curry, R.B., Jones, J.W., Boote, K.J. and Allen, L.H. (1990). Global climate change and U.S. agriculture, Nature, 345, 219-224.

Admas, R.M., Hurd, B.H. and Reily, J. (1999). A review of Impacts to U.S. Agricultural Resources, The Pew Center on Global Climate Change, Arlington, VA.

Azevedo, A.S.O.N. (1998). Assessment and Simulation of Atrazine as Influenced by Drainage and Irrigation - An Interface between RZWQM and Arcliew GIS, Doctor Thesis, Iowa State University: Ames, Iowa.

CCCma (2004). Canadian Centre for Climate Modelling and Analysis(CCCma).http://www.cccma.bc.ec.gc.ca/eng_index.shtml (accessed October 11, 2004).

Chakraborty, S., Tiedemann, A.V. and Teng, P.S. (2000). Climate change: potential impact on plant diseases. Environ. Pollut., 108, 317-326.

Chen, B., Huang, G., Li, Y.F. and Li, J. (2001b). Application of TNDVI data in a pesticide canopy emission model. In Proceedings of GeoSask2001 Conference - Spatial Technology, the Route to Better Decision, Information Services Corporation of Saskatchewan, Eds., Regina, Canada, 323-330.

Chen, B., Huang, G.H., Li, J.B., Li, Y.R. and Li, Y.F. (2001a). Integration of GIS with pesticides losses runoff model. International Archives of Photogrammetry and Remote Sensing, 34(2W2): 3744. 
Chen, B., Li, Y.F., Huang G.H., Huang, Y.F. and Li, Y.R. (2004) PELM: an integrated pesticide losses model for simulating pesticide pollution in a watershed system. J. Environ. Sci. Health, Pt. B, 39(4), 613-626.

Chen, B., Li, Y.F., Huang, G.H., Struger, J., Zhang, B.Y. and Wu, S.M. (2003). Modeling of atrazine loss in surface runoff from agricultural watershed, Water Qual. Res. J. Can., 38(4), 585-606.

Chen, C.C. and McCarl, B.A. (2001). An investigation of the relationship between pesticide usage and climate change. Clim. Change, 50, 475-487.

Davidson, R.H. and Lyon, W.F. (1987). Insect Pests of Farm, Garden and Orchard, John Wiley \& Sons, New York.

Finlayson, D.G. and MacCarthy, H.R. (1973). Pesticide residues in plants, in Environmental Pollution by Pesticides, Edwards, C.E., Eds., Plenum Press: New York.

Floyd, M.H., Thomas, F.H., Laura, O., Brian, H., James, P. and Robert, C. (1998) Application of C-CAP Protocol land-cover to nonpoint source water pollution potential spatial models in a coastal environment, Photogramm. Eng. Remote Sensing, 64(10): 1015 -1020 .

Freed, V.H. and Haque, R. (1973). Adsorption, movement, and distribution of pesticides in soils, in Pesticide Formulations, van Valkenburg, W., Eds., Marcel Dekker: New York.

Furtick, R.R. (1978). Weeds and world food production, in World Food, Pest Losses, and the Environmen, AAAS Selected Symp. 13, Pimentel, D., Eds., Westview Press, Boulder, CO.

GCRP (2000). U.S. National Assessment of the Potential Consequences of Climate Variability and Change, U.S. Global Change Research Program (GCRP), Washington, DC.

Hamaker, J.W. (1975). The interpretation of soil leaching experiments, in Environmental Dynamics of Pesticides, Haque, R, Freed, V.H., Eds., Plenum Press: New York.

Hatzios, K.K. and Penner, D. (1982). Metabolism of Herbicides in Higher Plants, CEPCO iv., Burgess Publ., Edina, MN.

Hess, P. (1995). Transect, Software for Managing Cropland Survey Data, 1996 User Guide, West Lafayette, Purdue University: West Lafayette, IN.

IPCC (1996). Climate Change 1995: The Science of Climate Change, Houghton, J.T., Meira Filho, L.G., Callander, B.A., Harris, N., Kattenberg A., Maskell, K., Eds., Contribution of Working Group I to the Second Assessment Report of the Intergovernmental Panel on Climate Change, Cambridge University Press, Cambridge.

IPCC (2000). Special Reports on Emissions Scenarios, Nakicenovic, $\mathrm{N}$, Swart, R, Eds., the Intergovernmental Panel on Climate Change (IPCC), Cambridge University Press: England.

IPCC (2001). Climate Change 2001: The Scientific Basis, Houghton J.T. (eds.): Cambridge University Press, 881-885.

Kaufman, D.D. (1983). Fate of toxic organic compounds in landapplied wastes, in Land Treatment of Hazardous Wastes, Parr, J.F., Marsh, P.B. and Kla, J.M., Eds., Noyes Data Corp.: Park Ridge, NJ.

Larson, S.J., Capel, P.D. and Majewski, M.S. (1997). Pesticides in Surface Waters - Distribution, Trends, and Governing Factors., Ann Arbor Press: Chelsea, Michigan.

Leonard, R.A., Knisel, W.G. and Still, D.A. (1987). GLEAMS: Groundwater Loading effects of agricultural management systems, Trans. ASAE, 30, 1403-1418.

Li, Y.F. and Bidleman, T.F. (2003). Correlation between global emissions of $\alpha$-hexachlorocyclohexane and its concentrations in the arctic air, J. Environ. Inf., 1(1), 52-57.

Li, Y.F., Li, Y.R., Huang, G.H, Struger, J., Wang, X., Chen, B. and Li, J.B. (2003a). Development of a decision support system for managing pesticide losses in agricultural watersheds, Int. J. Sedi. Res., 18(1), 60-73.
Li, Y.R., Huang, G.H., Li, Y.F., Struger, J. and Fischer, J.D. (2003b). A pesticide runoff model for simulating runoff losses pesticides from agricultural lands, Water Sci. Technol., 47, 33-40.

Lowe, J., Farrow, D., Pait, A., Arenstam, S. and Lavan, E. (1991). Fish Kills in Coastal Waters, 1980-1989: Strategic Environmental Assessment Division, ORCA / NOS / NOAA, Rockville, MD.

McCarl, B.A. and Reilly, J. (2000). Chapter 3 Sector Level Economics, in Agricultural Sector Assessment Report for U.S. Global Change Research Program, U.S. Global Change Research Program (USGCRP), Washington, DC.

Meier, W.P.F. (1985). Tierische Schadlinge und Pflanzenkrankheiten, Eidgenossiche Forschungsanstalt fr Landwirtschaftlichen Pflanzenbau, Auflage, ZrichRechkenholz.

Mendelsohn, R., Nordhaus, W. and Shaw, D. (1994). The impacts of global warming on agriculture: a ricardian analysis, American Economic Review, 84, 753-771.

New York State Department of Environmental Conservation (1990). Nonpoint Source Management Program, New York State Department of Environmental Conservation, Division of Water, Bureau of Water Quality management, Albany, New York.

Ohio Environmental Protection Agency (2002). Water quality standards -- Chapter 3745-1 of the Administrative Code, Division of Surface Water, Standards \& Technical Support Section, Ohio Environmental Protection Agency: Ohio.

Parker, C. and Fryer, J.D. (1975). Weed control problems causing major reductions in world food supplies, FAO Plant Protection Bulletin, 23, 83-95.

Parry, M.L., Porter, J.H. and Carter, T.R. (1990). Agriculture: climate change and its implications. Trends Ecol. Evol., 5, 318-322.

Patterson, D.T. (1993). Implications of global climate change for impact of weeds, insects, and plant diseases, in International Crop Sciences, vol. 1, Crop Science Society of America, Madison, Wisconsin.

Patterson, D.T. (1995). Weeds in a changing climate, Weed Sci., 43, 685-701.

Patterson, D.T., Westbrook, J.K., Joyce, R.J.V., Lingren, P.D. and Rogasik, J. (1999). Weeds, insects, and diseases, Clim. Change, 43, 711-727.

Reilly, J., Tubiello, F., Mccarl, B., Abler, D., Darwin, R., Fuglie, K., Hollinger, S., Izaurralde, C., Jagtap, S., Jones, J., Mearns, L., Ojima, D., Paul, E., Paustian, K., Riha, S., Rosenberg, N. and Rosenzweig C. (2003). U.S. agriculture and climate change: new results, Clim. Change, 57, 43-69.

Rosenzweig, C. and Parry, M.L. (1994) Potential impact of climate change on world food supply, Nature, 367, 133-138.

Sauer, A.N. (1998). Monitoring and Modeling Herbicide Runoff at Field and Subwatershed Scales: Master Thesis, University of Nebraska, Lincoln, Nebraska.

Southwood, T.R.E. and Comins, H.N. (1976). A synoptic population model, J. Anim. Ecol., 45(3): 949-965.

USDA (1991). State soil geographic data base (STATSGO): Soil Conservation Service Miscellaneous Publication 1492, U.S. Department of Agriculture: Washington, D.C..

USDA (1993). National Soil Survey Handbook, Title 430 - VI. Soil Survey, Soil Conservation Service, US Department of Agriculture: Washington, D.C.

USDA (1995). Root Zone Water Quality Model (RZWQM) V.3.0. User's Manual, GPSR Technical Report No.5. USDA-ARS Great Plains Systems Research Unit, Ft. Collins, CO.

USEPA (2002). Index of Watershed Indicators (IWI) Data Catalogs, U.S. Environmental Protection Agency, Athens, Ga.

USGS (2000). Water Quality in the Lake Erie-Lake Saint Clair Drainages Michigan, Ohio, Indiana, New York, and Pennsylvania, 1996-98. U.S. Geological Survey, Circular 1203: Reston, VA. 
USGS (2004). DEM STATUS GRAPHICS Dataset, EROS Dato Center, U.S. Geological Survey (USGS), U.S. Department of the Interior: Denver, $\mathrm{CO}$

USNOAA (2003). NOAA NCDC DAILY FSOD dataset, U.S. National Oceanic and Atmospheric Administration (NOAA) Office of Global Programs and Columbia University, Palisades, NY.

Wauchope, R.D. and Myers, R.S. (1985). Adsorption-desorption kinetics of atrazine and linuron in freshwater-sediment aqueous slurries, J. Environ. Qual., 14(1), 132-136.

Willis, G.H., McDowell, L.L., Smith, S. and Southwick, L.M. (1986). Permethrin washofffrom cotton plants by simulated rainfall, $J$. Environ. Qual., 15(2), 116-120.

Young, R.A., Onstad, C.A., Bosh, D.D. and Anderson, W. P. (1986). Agricultural Nonpoint source pollution models: A Watershed Analysis Tool, Model Documentation, Agricultural Research Service, U.S. Department of Agriculture, Morris, MN. 